\title{
Comparison of circulating metabolic and hepatic indices between fat- tailed and semi-fat-tailed ewes in different pre and post-partum periods
}

\author{
Aliasghar Chalmeh*, Mehrdad Pourjafar, Khalil Badiei, Ali Esmaeili, \\ and Mohammad Mazrouei Sebdani
}

Department of Clinical Sciences, School of Veterinary Medicine, Shiraz University, Shiraz, Iran

\begin{abstract}
CHALMEH, A., M. POURJAFAR, K. BADIEI, A. ESMAEILI, M. MAZROUEI SEBDANI: Comparison of circulating metabolic and hepatic indices between fattailed and semi-fat-tailed ewes in different pre and post-partum periods. Vet. arhiv 89, 43-53, 2019.
\end{abstract}

\section{ABSTRACT}

Tail fat is present in some breeds of sheep and they use this fat according to their energy requirements. We hypothesized that this fat deposition may interfere with the metabolism of ewes during pregnancy and lactogenesis. Hence, the present study was carried out to clarify the probable effect of tail fat on metabolic and hepatic biomarkers during different pre- and post-partum periods of fat-tailed in comparison with semifat-tailed ewes. Adult Mehraban $(\mathrm{n}=10)$ and Chios $(\mathrm{n}=10)$ ewes were selected and blood sampling was performed from all ewes at 2 and 4 months after mating, and 1, 2 and 3 months after parturition. Serum concentrations of glucose, total protein, albumin, globulin, aspartate aminotransferase, alanine transaminase, gamma glutamyl transferase, beta-hydroxy acid, non-esterified fatty acids, triglyceride, cholesterol, high, low and very low density lipoproteins, total, direct and indirect bilirubin were assayed in all specimens. Glucose in Chios ewes was significantly higher than in Mehraban at all the times studied. The circulating levels of aspartate aminotransferase, alanine transaminase, gamma glutamyl transferase, triglyceride, cholesterol, high, low and very low density lipoproteins, beta-hydroxy acid and non-esterified fatty acids were significantly higher in Mehraban ewes than in the Chios breed at different pre- and post parturient periods. The results of the current research revealed that metabolic and hepatic biomarkers alter during the pregnancy and lactation periods in sheep, which reflects the energy demands and metabolic alterations during these periods. Furthermore, it may be stated that the presence of tail fat in Mehraban ewes may alter the metabolic and hepatic functions in this breed. Tail fat may interfere with lipid metabolism and hepatic function during peri-parturient periods and it may be suggested that semi-fat-tailed breeds, such as Chios, may have more intensive metabolic pathways due to lower body fat storages.

Key words: tail fat; hepatic biomarkers; metabolic profile; Chios and Mehraban ewes

\footnotetext{
*Corresponding author:

Aliasghar Chalmeh, Department of Clinical Sciences, School of Veterinary Medicine, Shiraz University, Shiraz, Iran, P.O box: 71345; Phone: +98 7136138 700; Fax: +98 7132286 940; E-mail: achalmeh81@gmail.com
} 


\section{A. Chalmeh et al.: Metabolic and hepatic biomarkers in Chios and Mehraban ewes}

\section{Introduction}

Carbohydrate metabolism in ruminants has different characteristics compared to nonruminant animals. Dietary glucose in sheep, as a ruminant, is converted into short-chain volatile fatty acids in the rumen, and these fatty acids transfer to the liver to convert to glucose via hepatic gluconeogenesis (CHALMEH et al., 2015). This phenomenon keeps the ruminants at lower circulating glucose levels in comparison with non-ruminants, and predisposes them to negative energy balance at different metabolic periods in which the animal's energy demands rise. In pregnant and lactating ewes, the increased energy demands are not matched with glucose produced via hepatic gluconeogenesis, so different tissues manifest a relative energy deficit (THORN et al., 2012). This condition causes fatty acids mobilization from the adipose tissue to the liver in order to produce energy, which leads to increased levels of ketone bodies. Continuance of this condition may create different metabolic inconsistencies, such as ketosis and pregnancy toxemia (CONSTABLE et al., 2017). Previous studies have shown that many factors, such as food intake, starvation, endocrine status, age and sex, twin bearing and cold stress, can combat normal energy metabolism in ewes and contribute to the development of a negative energy balance in these animals (DZADZOVSKI et al., 2015). Ewes are commonly pregnant during the winter when they might be exposed to cold stress, which decreases insulin secretion and subsequently glucose utilization (SASAKI and TAKAHASHI, 1980), and in this disturbed energy balance, circulating metabolic parameters may be changed.

We hypothesized that the amount of reserved fat in the tail may affect the metabolism, and it may be considered as a factor that creates or combats the negative energy balance during pregnancy and lactogenesis in ewes in cold seasons. Hence; two different breeds of ewes were used in this study, Mehraban and Chios. The Mehraban is one of the oldest heavy-weight Iranian sheep with a fatty tail and coarse wool. They are raised mainly for twin lamb production in addition to wool as a secondary product. The Chios is a domestic semi-fat-tailed sheep, which was raised on the Greek island of Chios and it is now bred commonly for milk production.

The aim of the current research was to evaluate the circulating metabolic and hepatic biomarkers at critical metabolic states (pre and post partum periods) of Mehraban and Chios ewes, to identify the probable effect of reserved fat in the tail on the metabolism of these breeds. The results of the present study may describe the role of reserved body fats to prevent or escalate negative energy balance in fat-tailed ewes in comparison with semi-fat-tailed ewes.

\section{Materials and methods}

The present study was carried out in the winter of 2016 on adult Mehraban $(\mathrm{n}=10)$ and Chios $(n=10)$ ewes on a farm near Shiraz, Southwest Iran (latitude of $29^{\circ} 44^{\prime} \mathrm{N}$ and 


\section{A. Chalmeh et al.: Metabolic and hepatic biomarkers in Chios and Mehraban ewes}

longitude of $52^{\circ} 37^{\prime} \mathrm{E}, 1810 \mathrm{~m}$ above sea level). The ewes were housed in open-shed barns with free access to water and shade. Rations included alfalfa hay, corn silage, wheat straw, barley grain, wheat bran, cottonseed meal, urea, calcium carbonate, common salt $(\mathrm{NaCl})$ and vitamin-mineral premix (Table 1). All the animals were clinically healthy, had no history of debilitating disease and were free from internal and external parasites due to routine anti-parasitic programs at this farm. All ewes were 3 years-old with at least 2 successful parturitions. Pregnancy was diagnosed using a real-time ultrasound scanner equipped with a $3.5 \mathrm{MHz}$ sectorial convex probe (CTS-900V, SIUI, China). The ewes were examined transabdominally in a standing position. All ewes had a single fetus and had had 2 lactation periods. We studied these ewes at 2 and 4 months after mating, and 1 , 2 and 3 months after parturition.

Table 1. Chemical composition of feeds used for the studied sheep (all values except dry matter are shown on a dry matter basis)

\begin{tabular}{|l|c|c|c|c|c|c|c|c|}
\hline & \multicolumn{7}{|c|}{ Ration ingredients } \\
\cline { 2 - 10 } $\begin{array}{l}\text { Chemical } \\
\text { composition }\end{array}$ & $\begin{array}{c}\text { Alfalfa } \\
\text { hay }\end{array}$ & $\begin{array}{c}\text { Corn } \\
\text { silage }\end{array}$ & $\begin{array}{c}\text { Wheat } \\
\text { straw }\end{array}$ & $\begin{array}{c}\text { Barley } \\
\text { grain }\end{array}$ & $\begin{array}{c}\text { Wheat } \\
\text { bran }\end{array}$ & $\begin{array}{c}\text { Cottonseed } \\
\text { meal }\end{array}$ & $\begin{array}{c}\text { Urea } \\
(40 \% \text { N) }\end{array}$ & $\begin{array}{c}\text { Calcium } \\
\text { carbonate }\end{array}$ \\
\hline DM\% & 92 & 36 & 88 & 89 & 89 & 93 & 99 & 99 \\
\hline CP\% & 19 & 8 & 4 & 12 & 18 & 50 & 288 & 0 \\
\hline By-Pass\% & 60 & 40 & - & 30 & - & - & 0 & - \\
\hline EE\% & 3.0 & 2.7 & 1.5 & 2.0 & 4.8 & 3.1 & 0.0 & 0.0 \\
\hline CF\% & 26 & 23 & 42 & 6 & 11 & 12 & 0 & 0 \\
\hline ADF\% & 35 & 28 & 56 & 7 & 14 & - & 0 & 0 \\
\hline NDF\% & 45 & 50 & 85 & 20 & 47 & 40 & 0 & 0 \\
\hline Ash\% & 11 & 7 & 7 & 3 & 7 & 8 & 0 & 99 \\
\hline Ca\% & 1.4 & 0.3 & 0.2 & 0.1 & 0.1 & 0.5 & 0.0 & 39.0 \\
\hline P\% & 0.25 & 0.20 & 0.08 & 0.42 & 1.30 & 0.80 & 0.00 & 0.04 \\
\hline K\% & 2.7 & 1.0 & 1.2 & 0.5 & 1.4 & 1.1 & 0.0 & 0.0 \\
\hline S\% & 0.24 & 0.10 & 0.14 & 0.16 & 0.25 & 0.33 & 0.00 & 0.09 \\
\hline Zn (ppm) & 19 & 24 & 7 & 25 & 105 & 21 & 0 & 0 \\
\hline TDN\% & 61 & 69 & 44 & 83 & 70 & 65 & 0 & 0 \\
\hline $\begin{array}{l}\text { DE } \\
\text { (Mcal/lb) }\end{array}$ & 1.22 & 1.38 & 0.88 & 1.66 & 1.40 & 1.30 & 0.00 & 0.00 \\
\hline $\begin{array}{l}\text { NEm } \\
\text { (Mcal/lb) }\end{array}$ & 0.61 & 0.70 & 0.43 & 0.89 & 0.72 & 0.65 & 0.00 & 0.00 \\
\hline $\begin{array}{l}\text { NEg } \\
\text { (Mcal/lb) }\end{array}$ & 0.31 & 0.43 & 0.01 & 0.60 & 0.44 & 0.37 & 0.00 & 0.00 \\
\hline
\end{tabular}

DM: dry matter; CP: crude protein; EE: crude fat; CF: crude fiber; ADF: acid detergent fiber; NDF: neutral detergent fiber; TDN: total digestible nutrients; DE: digestible energy; NEm: net energy for maintenance; NEg: net energy for gain. Trace mineral added to ration (expressed as ppm): cobalt: 0.11 ; copper 10-18; iodine: $0.3-$ 0.4; iron: 13-130; manganese: 14-24; selenium: 0.30 and zinc: 22-70. 
Blood sampling was performed into plain tubes from each ewe at the different times studied. Immediately after blood collection, sera were separated by centrifugation for 10 minutes at $3,000 \times \mathrm{g}$ and stored at $-22{ }^{\circ} \mathrm{C}$ until assayed. Glucose was assayed by the enzymatic (glucose oxidase) colorimetric method (ZistChems ${ }^{\circledR}$, Tehran, Iran). Total protein was assayed by Biuret and albumin by bromocresol green methods (PasrAzemon ${ }^{\circledR}$, Iran). Globulin was calculated as total protein minus albumin. Total and direct bilirubin was analyzed by the 2,4dichloroaniline photometric method (PasrAzemon ${ }^{\circledR}$, Iran). Indirect bilirubin was calculated as total bilirubin minus direct bilirubin. Values of serum aspartate aminotransferase (AST), alanine transaminase (ALT) and gamma glutamyltransferase (GGT) were measured with an Integra 800 auto-analyzer (Roche-Cobes, Switzerland). Beta-hydroxy acid (BHBA) and non-esterified fatty acid (NEFA) were assayed by the colorimetric method (Ranbut ${ }^{\mathbb{B}}$, Ireland). The sera were analyzed for cholesterol by a modified Abell-Kendall/Levey-Brodie (A-K) method (BURTIS and ASHWOOD, 1994), triglyceride (TG) by the enzymatic procedure of McGOWAN et al. (1983). Lipoproteins were isolated using a combination of precipitation and ultra-centrifugation. High density lipoprotein (HDL)-cholesterol was measured using the precipitation method. In the first step, the precipitation reagent (sodium phosphotungstate with magnesium chloride) was added to the serum to aggregate non-HDL lipoproteins, which were sedimented by centrifugation $(10,000 \times \mathrm{g}$ for $5 \mathrm{~min})$. The residual cholesterol was then measured by the enzymatic method (BURTIS and ASHWOOD, 1994). High density lipoprotein (LDL)cholesterol was calculated as the difference between the total cholesterol measured in the precipitate and in the HDL fraction, minus $0.2 \times$ triglyceride $(\mathrm{LDL}=$ total cholesterol-HDL cholesterol- $0.2 \times \mathrm{TG}$ ). Very low density lipoprotein (VLDL)-cholesterol was estimated as one-fifth of the concentration of triglycerides (FRIEDEWALD et al., 1972).

All data are presented as mean \pm standard deviation (SD). Differences between the breeds in the averages of concentrations of each parameter at similar periods were analyzed by two independent samples $t$-test. Repeated Measures ANOVA was used to evaluate the changing patterns of each parameter for each breed, separately, from 2 months after mating to 3 months after parturition, using SPSS software (IBM-SPSS for Windows, version 20, SPSS Inc, Chicago, IL, USA, 2011). The level of significance was set at $\mathrm{P}<0.05$.

\section{Results}

The circulating levels of different metabolic and hepatic indices at different pre- and post-partum periods in Mehraban compared with Chios ewes are presented in Table 2. Glucose in Chios ewes was significantly higher than in Mehraban at all times studied $(\mathrm{P}<0.05)$. The circulating levels of GGT, AST, ALT, TG, cholesterol, HDL, LDL, VLDL, NEFA and BHBA in Mehraban ewes were significantly higher than in the Chios breed 
A. Chalmeh et al.: Metabolic and hepatic biomarkers in Chios and Mehraban ewes

at different pre- and post-parturient periods $(\mathrm{P}<0.05)$. Total protein, albumin, globulin, total, direct and indirect bilirubin in Chios ewes showed no significant differences to the Mehraban ewes $(\mathrm{P}>0.05)$. Repeated Measures ANOVA showed that the changing patterns of all evaluated parameters from 2 months after mating to 3 months after parturition, were significant in both breeds studied $(\mathrm{P}<0.05)$.

Table 2. Circulating levels of different metabolic and hepatic indices (Mean $\pm \mathrm{SD}$ ) at different preand post-partum periods of Mehraban $(n=10)$ in comparison with Chios $(n=10)$ ewes

\begin{tabular}{|c|c|c|c|c|c|c|}
\hline Parameters & Breeds & $\begin{array}{l}2 \text { months } \\
\text { after mating }\end{array}$ & $\begin{array}{l}4 \text { months } \\
\text { after mating }\end{array}$ & $\begin{array}{l}1 \text { month after } \\
\text { parturition }\end{array}$ & $\begin{array}{c}2 \text { months after } \\
\text { parturition }\end{array}$ & $\begin{array}{c}3 \text { months afte } \\
\text { parturition }\end{array}$ \\
\hline \multirow{2}{*}{$\begin{array}{l}\text { Glucose } \\
(\mathrm{mg} / \mathrm{dL})\end{array}$} & & $82.10 \pm 4.32^{\mathrm{a}}$ & $99.18 \pm 8.64^{\mathrm{a}}$ & $83.14 \pm 10.11^{\mathrm{a}}$ & $89.21 \pm 4.57^{\mathrm{a}}$ & $91.42 \pm 6.32^{\mathrm{a}}$ \\
\hline & & $62.40 \pm 0.24^{b}$ & $87.40 \pm 2.20^{b}$ & $66.00 \pm 0.01^{\mathrm{b}}$ & $76.40 \pm 0.97^{b}$ & $71.00 \pm 6.12^{b}$ \\
\hline \multirow{2}{*}{$\begin{array}{l}\text { Tot. protein } \\
\text { (g/dL) }\end{array}$} & & $7.24 \pm 0.84$ & $6.89 \pm 1.02$ & $5.68 \pm 0.79$ & $5.01 \pm 0.54$ & $5.95 \pm 0.91$ \\
\hline & & $6.52 \pm 1.12$ & $7.01 \pm 0.94$ & $5.32 \pm 0.86$ & $5.87 \pm 1.01$ & $6.22 \pm 0.67$ \\
\hline \multirow{2}{*}{$\begin{array}{l}\text { Albumin } \\
\text { (g/dL) }\end{array}$} & & $2.48 \pm 1.01$ & $2.51 \pm 0.78$ & $2.54 \pm 0.34$ & $2.09 \pm 0.37$ & $2.44 \pm 0.45$ \\
\hline & & $2.21 \pm 0.87$ & $2.12 \pm 0.54$ & $2.05 \pm 0.37$ & $1.98 \pm 0.72$ & $2.06 \pm 0.66$ \\
\hline \multirow{2}{*}{$\begin{array}{l}\text { Globulin } \\
\text { (g/dL) }\end{array}$} & & $4.08 \pm 0.67$ & $4.22 \pm 0.77$ & $3.97 \pm 0.38$ & $3.54 \pm 0.48$ & $3.69 \pm 0.87$ \\
\hline & & $3.87 \pm 0.42$ & $4.56 \pm 0.64$ & & $3.11 \pm 0.97$ & $3.66 \pm 0.66$ \\
\hline \multirow{2}{*}{$\begin{array}{l}\text { Tot. bilirub. } \\
\text { (mg/dL) }\end{array}$} & & $3.87 \pm 0.34$ & & & & $3.21 \pm 0.25$ \\
\hline & Mehraban & $3.41 \pm 0.14$ & $3.51 \pm 0.87$ & .66 & \pm 0.81 & 0.34 \\
\hline \multirow{2}{*}{$\begin{array}{l}\text { Dir. bilirub. } \\
(\mathrm{mg} / \mathrm{dL})\end{array}$} & & $0.12 \pm 0.02$ & $0.14 \pm 0$ & $0.12 \pm$ & & \\
\hline & Mehraban & $0.10 \pm 0.01$ & $0.15 \pm 0.02$ & $0.14 \pm 0.01$ & $0.15 \pm 0.02$ & $0.15 \pm 0.01$ \\
\hline \multirow{2}{*}{$\begin{array}{l}\text { Ind. bilirub. } \\
(\mathrm{mg} / \mathrm{dL})\end{array}$} & & $2.91 \pm 0.36$ & & & & \\
\hline & & $2.87 \pm 0.54$ & $2.84 \pm 0.31$ & $2.64 \pm 0.24$ & $2.75 \pm 0.46$ & $2.80 \pm 0.61$ \\
\hline \multirow{2}{*}{$\begin{array}{l}\mathrm{GGT} \\
(\mathrm{U} / \mathrm{L})\end{array}$} & & $24.41 \pm 4.02^{\mathrm{a}}$ & $24.32 \pm 2.01^{\mathrm{a}}$ & $24.61 \pm 3.22^{\mathrm{a}}$ & $25.11 \pm 2.11^{\mathrm{a}}$ & $25.24 \pm 1.97^{\mathrm{a}}$ \\
\hline & Mehraban & $27.61 \pm 3.22^{\mathrm{b}}$ & $29.22 \pm 3.87^{b}$ & $28.11 \pm 2.97^{\mathrm{b}}$ & $28.79 \pm 3.24^{\mathrm{b}}$ & $27.94 \pm 2.58^{b}$ \\
\hline \multirow{2}{*}{$\begin{array}{l}\text { AST } \\
(\mathrm{U} / \mathrm{L})\end{array}$} & & $00.24 \pm 10.21^{\mathrm{a}}$ & $110.46 \pm 9.21^{\mathrm{a}}$ & $112.47 \pm 9.11^{\mathrm{a}}$ & $110.28 \pm 11.01^{\mathrm{a}}$ & $113.74 \pm 9.89^{a}$ \\
\hline & Mehraban & $104.87 \pm 7.22^{b}$ & $126.91 \pm 6.48^{b}$ & $118.21 \pm 12.10^{b}$ & $116.24 \pm 11.32^{b}$ & $115.31 \pm 13.21^{b}$ \\
\hline \multirow{2}{*}{$\begin{array}{l}\text { ALT } \\
(\mathrm{U} / \mathrm{L})\end{array}$} & & $20.10 \pm 1.02^{\mathrm{a}}$ & $19.51 \pm 1.21^{\mathrm{a}}$ & $20.10 \pm 8.31^{\mathrm{a}}$ & & $19.14 \pm 1.14^{\mathrm{a}}$ \\
\hline & Uehraban & $21.87 \pm 3.41^{b}$ & $33.24 \pm 4.11^{b}$ & $25.78 \pm 3.67^{b}$ & $23.24 \pm 3.21^{\mathrm{b}}$ & $24.10 \pm 3.25^{b}$ \\
\hline \multirow{2}{*}{$\begin{array}{l}\text { Triglyceride } \\
(\mathrm{mg} / \mathrm{dL})\end{array}$} & & $14.57 \pm 3.22^{\mathrm{a}}$ & $14.66 \pm 2.87^{\mathrm{a}}$ & $15.10 \pm 2.66^{\mathrm{b}}$ & $16.12 \pm 3.45^{\mathrm{a}}$ & $15.18 \pm 2.88^{\mathrm{a}}$ \\
\hline & Mehraban & $22.40 \pm 7.66^{b}$ & $29.00 \pm 2.23^{b}$ & $24.00 \pm 3.01^{\mathrm{b}}$ & $22.80 \pm 7.12^{b}$ & $21.80 \pm 3.83^{b}$ \\
\hline \multirow{2}{*}{$\begin{array}{l}\text { Cholesterol } \\
(\mathrm{mg} / \mathrm{dL})\end{array}$} & & $48.97 \pm 3.22^{\mathrm{a}}$ & $45.61 \pm 3.22^{\mathrm{a}}$ & $32.68 \pm 5.67^{\mathrm{a}}$ & $39.91 \pm 6.47^{\mathrm{a}}$ & $41.66 \pm 4.31^{\mathrm{a}}$ \\
\hline & Mehraban & $61.20 \pm 4.31^{b}$ & $72.20 \pm 3.78^{b}$ & $64.00 \pm 8.01^{\mathrm{b}}$ & $62.80 \pm 5.33^{b}$ & $65.60 \pm 8.62^{b}$ \\
\hline \multirow{2}{*}{$\begin{array}{l}\mathrm{HDL} \\
(\mathrm{mg} / \mathrm{dL})\end{array}$} & & $0.98 \pm 0.09^{\mathrm{a}}$ & $0.96 \pm 0.12^{\mathrm{a}}$ & $0.89 \pm 0.21^{\mathrm{a}}$ & $0.88 \pm 0.20^{\mathrm{a}}$ & $0.94 \pm 0.22^{\mathrm{a}}$ \\
\hline & Mehraban & $1.30 \pm 0.01^{\mathrm{b}}$ & $1.05 \pm 0.10^{\mathrm{b}}$ & $1.20 \pm 0.11^{\mathrm{b}}$ & $1.10 \pm 0.10^{\mathrm{b}}$ & $1.06 \pm 0.05^{\mathrm{b}}$ \\
\hline \multirow{2}{*}{$\begin{array}{l}\mathrm{LDL} \\
(\mathrm{mg} / \mathrm{dL})\end{array}$} & Chios & $48.21 \pm 3.61^{\mathrm{a}}$ & $48.66 \pm 4.22^{\mathrm{a}}$ & $50.20 \pm 2.14^{\mathrm{a}}$ & $49.95 \pm 3.12^{\mathrm{a}}$ & $50.22 \pm 5.11^{\mathrm{a}}$ \\
\hline & Mehraban & $58.02 \pm 7.77^{b}$ & $68.80 \pm 2.23^{b}$ & $62.00 \pm 4.01^{\mathrm{b}}$ & $60.54 \pm 5.91^{b}$ & $58.18 \pm 7.91^{b}$ \\
\hline \multirow{2}{*}{$\begin{array}{l}\text { VLDL } \\
(\mathrm{mg} / \mathrm{dL})\end{array}$} & & $4.22 \pm 0.89^{\mathrm{a}}$ & $4.31 \pm 0.78^{\mathrm{a}}$ & $4.89 \pm 0.95^{\mathrm{a}}$ & $4.97 \pm 0.91^{\mathrm{a}}$ & $4.18 \pm 0.58^{\mathrm{a}}$ \\
\hline & Mehraban & $4.88 \pm 1.53^{b}$ & $4.40 \pm 0.44^{b}$ & $5.80 \pm 0.71^{b}$ & $5.16 \pm 1.42^{b}$ & $4.36 \pm 0.76^{b}$ \\
\hline
\end{tabular}




\section{A. Chalmeh et al.: Metabolic and hepatic biomarkers in Chios and Mehraban ewes}

Table 2. Circulating levels of different metabolic and hepatic indices (Mean $\pm \mathrm{SD}$ ) at different pre- and post-partum periods of Mehraban $(n=10)$ in comparison with Chios $(n=10)$ ewes (continued)

\begin{tabular}{|l|l|c|c|c|c|c|}
\hline \multirow{2}{*}{ Parameters } & Breeds & $\begin{array}{c}2 \text { months } \\
\text { after mating }\end{array}$ & $\begin{array}{c}4 \text { months } \\
\text { after mating }\end{array}$ & $\begin{array}{c}1 \text { month after } \\
\text { parturition }\end{array}$ & $\begin{array}{c}\text { months after } \\
\text { parturition }\end{array}$ & $\begin{array}{c}\text { months after } \\
\text { parturition }\end{array}$ \\
\hline $\begin{array}{l}\text { BHBA } \\
(\mu \mathrm{mol} / \mathrm{L})\end{array}$ & Chios & $98.60 \pm 3.13^{\mathrm{a}}$ & $120.31 \pm 9.83^{\mathrm{a}}$ & $94.00 \pm 8.01^{\mathrm{a}}$ & $88.60 \pm 18.17^{\mathrm{a}}$ & $89.51 \pm 12.29^{\mathrm{a}}$ \\
\cline { 2 - 7 } & Mehraban & $132.75 \pm 7.21^{\mathrm{b}}$ & $156.79 \pm 8.32^{\mathrm{b}}$ & $132.81 \pm 6.41^{\mathrm{b}}$ & $128.78 \pm 7.28^{\mathrm{b}}$ & $122.71 \pm 6.33^{\mathrm{b}}$ \\
\hline \multirow{2}{*}{$\begin{array}{l}\text { NEFA } \\
(\mathrm{mmol} / \mathrm{L})\end{array}$} & Chios & $131.00 \pm 11.90^{\mathrm{a}}$ & $141.20 \pm 8.49^{\mathrm{a}}$ & $129.00 \pm 7.01^{\mathrm{a}}$ & $137.20 \pm 10.57^{\mathrm{a}}$ & $123.60 \pm 11.78^{\mathrm{a}}$ \\
\cline { 2 - 7 } & Mehraban & $172.34 \pm 4.57^{\mathrm{b}}$ & $186.78 \pm 9.13^{\mathrm{b}}$ & $145.78 \pm 8.15^{\mathrm{b}}$ & $144.25 \pm 6.33^{\mathrm{b}}$ & $149.29 \pm 7.25^{\mathrm{b}}$ \\
\hline
\end{tabular}

GGT: gamma glutamyltransferase; AST: aspartate aminotransferase; ALT: alanine transaminase; HDL: high density lipoprotein; LDL: low density lipoprotein; VLDL: very density lipoprotein; BHBA: beta-hydroxy acid; NEFA: non-esterified fatty acid. ${ }^{a, b}$ : Different letters indicate significant differences between the averages of concentrations of each parameter at similar periods between the two breeds $(\mathrm{P}<0.05)$.

\section{Discussion}

Tail fat in some breeds of sheep is adipose tissue deposited in the hind parts of the sheep on both sides of its tail. These fats are subsequently used following energy demands similar to a camel's hump. There are different breeds of sheep which have fat depositions in their tails and some breeds are not fat-tailed. We hypothesized that this fat deposition may interfere with the metabolism of ewes during pregnancy and lactogenesis. Hence, the present study was carried out to clarify the probable effect of tail fat on metabolic and hepatic biomarkers during different the pre- and post-partum periods in fat-tailed in comparison with semi-fat-tailed ewes.

Gluconeogenesis in ruminants does not increase with increased fetal demands during pregnancy and it may cause energy deficit in maternal tissues (RAOOFI et al., 2013). Low concentrations of serum glucose in pregnant ewes are probably the consequence of inappropriate gluconeogenesis in the liver from glucogenoplastic precursors, such as propionate, that originate from rumen fermentation. Food deprivation, which is evident in pregnant ewes due to lower gastrointestinal capacity, causes a lack of propionate precursors for glucose production (WANG et al., 2012; THORN et al., 2012). The results of the present study showed that glucose levels at 4 months' pregnancy were higher than at other periods in both breeds (Table 2). Serum cortisol levels at the end of pregnancy increase and enhance gluconeogenesis in ewes (CONSTABLE et al., 2017) and this may be a reason for increased glucose levels at this period (CHALMEH and HAJIMOHAMMADI, 2016). Furthermore, circulating glucose levels in Chios ewes were significantly higher than in Mehraban ewes at all times studied (Table 2; $\mathrm{P}<0.05$ ).

Biochemical pathways are further complicated within appropriate beta-oxidation of acetate and butyrate, leading to increased production of acetil-Co-A by hepatocytes. This product is a precursor for acetoacetyl-Co-A. Acetoacetyl-Co-A is a primordial molecule 


\section{A. Chalmeh et al.: Metabolic and hepatic biomarkers in Chios and Mehraban ewes}

for ketone bodies, with a strong effect on acid-base status. This molecule is converted into a very unstable molecule, acetoacetate. The reduction of acetoacetate produces BHBA, while irreversible decarboxilation of acetoacetate produces aceton molecules. Excessive concentrations of serum BHBA cannot be utilized by extrahepatic tissue, and therefore the serum level of BHBA remains high (CONSTABLE et al., 2017). In this research, serum BHBA values at 4 months' pregnancy were higher than at other periods in both breeds (Table 2). BHBA is an indirect indicator of negative energy balance and the difference in BHBA concentrations between pregnant and non-pregnant ewes may be due to the decreased alimentary energy resources in pregnant sheep (DZADZOVSKI et al., 2015). Circulating BHBA in Chios were significantly lower than in Mehraban ewes at all studied time periods (Table 2; $\mathrm{P}<0.05$ ). Based on this result, it seems that Chios ewes have more ability to produce energy and combat ketotic conditions.

Insufficient energy derived by carbohydrate metabolism causes lipolysis, but energy derived from free fatty acids cannot be adequately used in the Krebs cycle, because of a lack of oxalacetate, derived from glycogenic precursors. The hepatic capacity for metabolizing NEFA released from adipose tissue is overloaded. Physiologically, NEFA can be re-esterified in triglycerides which are included in the formation of VLDL for secretion in blood (CONSTABLE et al., 2017). Sheep have a very low capacity for production of VLDL (HENZE et al., 1998), especially breeding and non-breeding sheep compared with sheep in lactation, and thereby they are not able to produce enough VLDL in a condition of compromised lipid metabolism in hepatocytes. In that case, TG cannot be removed from hepatocytes, so it remains in the hepatocytes causing hepatic insufficiency (EMMISON et al., 1991).

The results of the current research showed that circulating lipids at 4 months' pregnancy were higher than at other periods in the Mehraban ewes. The highest concentrations of TGs, cholesterol and LDL during late pregnancy in Mehrabans compared to the nonpregnancy periods could be explained as a consequence of the more severe negative energy balance and more difficult transport of the lipoproteins. Circulating lipid profiles in Mehraban ewes were significantly higher than in Chios at all time periods studied (Table 2; $\mathrm{P}<0.05$ ). It may be suggested that the negative energy balance in Chios ewes is lower than in Mehrabans, furthermore, the presence of tail fat in Mehraban ewes may be considered as a factor that maintains the serum lipid profile in this breed.

Since liver has a key role in glucose production and lipid metabolism in ruminants, we hypothesized that liver functions may alter during pregnancy and lactation in ewes. Furthermore, we would have expected that hepatic functions in fat-tailed may differ from semi-fat-tailed breeds. Hence, hepatic function biomarkers were evaluated during the study. 


\section{A. Chalmeh et al.: Metabolic and hepatic biomarkers in Chios and Mehraban ewes}

In the present study, serum AST at 4 months' pregnancy in Mehraban ewes was higher than at other periods (Table 2). It seems that at this period, Mehraban ewes suffered from severe liver impairment and the liver's capacity to maintain its functions decreased when compared to non-pregnant ewes. AST is a liver enzyme that enhances the process of transamination, with oxalacetate, a main metabolite in the Krebs cycle, as a final product. As a cytosol enzyme with many isoformes, it can easily pass the hepatocyte membrane, so increased serum activity of AST indicates over-loaded hepatocyte activity. Homeostatic regulatory mechanisms are disrupted because of the neuro-endocrinological requirements in the period of late gestation and lambing. This critical period in sheep is further complicated by high metabolic energy demand (GREENFIELD et al., 2000). The increase in serum ALT, AST and GGT activities of Mehraban ewes in pregnancy indicated an increase in hepatic metabolism (Table 2). Changes in the activities of these enzymes may be related to reduced dry matter intake around parturition, and may lead to hepatic lipidosis and alter the normal function of the liver (SERDARU et al., 2011). All hepatic enzymes were in the normal reference ranges in both breeds (RADOSTITS et al., 2007) but the results showed that circulating hepatic enzymes in fat-tailed ewes were significantly higher than in the semi-fat-tailed breed at all studied time periods (Table 2; $\mathrm{P}<0.05)$. It may be stated that liver function in Chios is more potent than Mehraban to promote metabolic pathways, and hepatic damage in Chios is lower than in Mehraban.

Other indicators of liver dysfunction are serum proteins levels, especially albumin, which decrease during hepatic insufficiency (DZADZOVSKI et al., 2015). Particularly, the serum protein fraction pattern could provide information about dehydration, plasma volume expansion and hepatic function (PICCIONE et al., 2012). Mild dehydration of ewes appears as a result of the osmotic activity of ketone bodies, because they are very strong acids, causing a keto-acidotic condition (PICCIONE et al., 2012). Decreased total protein and albumin during lactation in Mehraban ewes could be explained by the rapid extraction of immunoglobulin from the plasma during the last few months of pregnancy, when colostrum is being formed in the mammary gland (KANEKO et al., 2008). In contrast, YOKUS et al. (2006) observed no significant changes in total protein levels with different reproductive status. However, KARAPEHLIVAN et al. (2007) and ANTUNOVIC et al. (2011) reported significantly high concentrations of total protein and albumin in pregnant ewes compared to not pregnant.

Bilirubin is the main bile pigment in the plasma of animals derived from hemoglobin breakdown. The icterus index, a reflection of total bilirubin level in plasma, is a tool used for disease diagnosis and prognosis (COLES, 1986). In this investigation, there were no significant changes in the patterns of total, direct and indirect bilirubin during the study. Furthermore, there were no significant differences between the breeds at any time periods studied. 
A. Chalmeh et al.: Metabolic and hepatic biomarkers in Chios and Mehraban ewes

\section{Conclusion}

The results of the current research revealed that metabolic and hepatic biomarkers alter during pregnancy and lactation periods in sheep, which reflects the energy demands and metabolic alterations during these periods. Furthermore, it may be stated that the presence of tail fat in Mehraban ewes may alter the metabolic and hepatic functions in this breed. Tail fat may interfere with lipid metabolism and hepatic function during the peri-parturient period and semi-fat-tailed breeds such as Chios may have more intensive metabolic pathways due to lower body fat storages. On the basis of our hypothesis and the results of the hepatic and metabolic indices evaluated, we concluded that the hepatic and metabolic performance of Chios was more efficient than in Mehraban ewes in combating the negative energy balance. However, according to the results, a negative energy balance was still present in both breeds.

\section{References}

ANTUNOVIC, Z., J. NOVOSELEC, H. SAUERWEIN, M. SPERANDA, M. VEGARA, V. PAVIC (2011): Blood metabolic profile and some of hormones concentration in ewes during different physiological status. Bulg. J. Agric. Sci. 17, 687-695.

BURTIS, C. A., E. R. ASHWOOD (1994): Tietz Textbook of Clinical Chemistry. (W.B. Saunders Com, $2^{\text {nd }}$ ed.), Philadelphia, pp. 735-888.

CHALMEH A., A. HAJIMOHAMMADI (2016): Circulating metabolic hormones in different metabolic states of high producing Holstein dairy cows. Iran. J. Vet. Med. 10, 277-284.

CHALMEH, A., A. HAJIMOHAMMADI, S. NAZIFI (2015): Endocrine and metabolic responses of high producing Holstein dairy cows to glucose tolerance test based on the stage of lactation. Livest. Sci. 181, 179-186.

DOI: $10.1016 /$ j.livsci.2015.09.014

COLES, E. H. (1986): Veterinary Clinical Pathology. (W.B. Saunders Com., $4^{\text {th }}$ ed.), Philadelphia.

CONSTABLE, P., K. W. HINCHCLIFF, S. DONE, W. GRUENBERG (2017): Veterinary Medicine: A textbook of the diseases of cattle, horses, sheep, pigs and goats. $11^{\text {th }}$ ed., Saunders Ltd.

DZADZOVSKI, I., I. CELESKA, I. ULCHAR, A. JANEVSKI, D. KIROVSKI (2015): Influence of the season on the metabolic profile in Chios sheep. Mac. Vet. Rev. 38, 183-188.

DOI: 10.14432/j.macvetrev.2015.06.048

EMMISON, N., L.AGIUS, V.A. ZAMMIT (1991): Regulation of fatty acid metabolism and gluconeogenesis by growth hormone and insulin in sheep hepatocyte cultures - Effects of lactation and pregnancy. Biochem. J. 274, 21-26.

DOI: $10.1042 /$ bj2740021

FRIEDEWALD, W. T., R. I. LEVY, D. S. FREDRICKSON (1972): Estimation of the concentration of low density lipoprotein cholesterol without the use of the preparative ultracentrifuge. Clin. Chem. 18, 499-502. 
A. Chalmeh et al.: Metabolic and hepatic biomarkers in Chios and Mehraban ewes

GREENFIELD, R. B., M. J. CECAVA, T. R. JOHNSON, S. S. DONKIN (2000): Impact of dietary protein amount and rumen undegradability on intake, peripartum liver triglyceride, plasma metabolites and milk production in transition dairy cattle. J. Dairy Sci. 83, 703-710.

DOI: $10.3168 /$ jds.S0022-0302(00)74932-0

HENZE, P., K. BICKHARDT, H. FUHRMANN, H. P. SALLMANN (1998): Spontaneous pregnancy toxaemia (ketosis) in sheep and the role of insulin. Zentralbl. Veterinarmed A. 45, 255-266.

DOI: 10.1111/j.1439-0442.1998.tb00825.x

KANEKO, J. J., J. W. HARVEY, M. L. BRUSS (2008): Clinical Biochemistry of Domestic Animals. $6^{\text {th }}$ ed., Elsevier/Academic Press, Amsterdam.

KARAPEHLIVAN, M., E. ATAKISI, O. ATAKISI, R. YUCAYURT, S. M. PANCARCI (2007): Blood biochemical parameters during the lactation and dry period in Tuj ewes. Small Rumin. Res. 73, 267-271.

DOI: $10.1016 /$ j.smallrumres.2006.12.006

McGOWAN, M. W., J. D. ARTISS, D. R. STRANDBERGH, B. ZAK (1983): A peroxidase coupled method for the colorimetric determination of serum triglycerides. Clin. Chem. 29, 538-542.

PiCCIONE, G., D. AlBerghinA, S. MARAFIOTI, C. GIANNETTO, S. CASElla, A. ASSENZA, F. FAZIO (2012): Electrophoretic serum protein fraction profile during the different physiological phases in Comisana ewes. Reprod. Domest. Anim. 47, 591-595.

DOI: 10.1111/j.1439-0531.2011.01925.x

RADOSTITS, O. M., C. C. GAY, K. W. HINCHCLIFF, P. D. CONSTABLE (2007): Veterinary Medicine: A Textbook of the Diseases of Cattle, Horses, Sheep, Pigs and Goats. A 10th ed., Elsevier Health Sciences, Philadelphia, PA, USA.

RAOOFI, A., M. JAFARIAN, S. SAFI, M. VATANKHAH (2013): Fluctuations in energy-related metabolites during the peri-parturition period in Lori-Bakhtiari ewes. Small Rumin. Res. 109, 64-68.

DOI: 10.1016/j.smallrumres.2012.06.012

SASAKI, Y., H. TAKAHASHI (1980): Insulin secretion in sheep exposed to cold. J. Physiol. 306, 323-335.

DOI: $10.1113 /$ jphysiol.1980.sp013399

SERDARU, M., I. NICOLAE, M. ENCULESCU, A. BOTA, E. BOLOCAN (2011): Seasonal variations of some hematological and biochemical parameters of the Carpathian Romanian buffaloes. I. The winter period. Anim. Sci. Biotechnol. 44, 94-98.

THORN, S. R., S. M. SEKAR, J. R. LAVEZZI, M. C. O’MEARA, L. D. BROWN, W. W. HAY JR., P. J. ROZANCE (2012): A physiological increase in insulin suppresses gluconeogenic gene activation in fetal sheep with sustained hypoglycemia. Am. J. Physiol. Regul. Integr. Comp. Physiol. 303, 861-869.

DOI: 10.1152/ajpregu.00331.2012 
A. Chalmeh et al.: Metabolic and hepatic biomarkers in Chios and Mehraban ewes

YOKUS, B., D. U. CAKIR, Z. KANAY, T. GULTEN, E. UYSAL (2006): Effects of seasonal and physiological variations on the serum chemistry, vitamins and thyroid hormone concentrations in sheep. J. Vet. Med. A. 53, 271-276.

DOI: $10.1111 /$ j.1439-0442.2006.00831.X

WANG, J., X. ZHU, C. CHEN, X. LI, Y. GAO, P. LI, Y. ZHANG, M. LONG, Z. WANG, G. LIU (2012): Effect of insulin-like growth factor-1 (IGF-1) on the gluconeogenesis in calf hepatocytes cultured in vitro. Mol. Cell Biochem. 362, 87-91.

DOI: $10.1007 / \mathrm{s} 11010-011-1130-9$

Received: 25 November 2017

Accepted: 24 May 2018

CHALMEH, A., M. POURJAFAR, K. BADIEI, A. ESMAEILI, M. MAZROUEI SEBDANI: Usporedba metaboličkih i jetrenih pokazatelja u krvi masnorepih i polumasnorepih pasmina ovaca prije i poslije janjenja. Vet. arhiv 89, 43-53, 2019.

\section{SAŽETAK}

Masnoća u repu nekih pasmina ovaca služi kao energetska zaliha organizma. Pretpostavili smo da ta zaliha masti može biti povezana s metabolizmom ovaca tijekom bređosti i laktacije. U skladu s tim cilj ovoga istraživanja bio je pojasniti mogući učinak masnoće u repu na metaboličke i jetrene pokazatelje u razdoblju prije i poslije janjenja kod masnorepih i polumasnorepih ovaca. Odabrane su odrasle ovce pasmina Mehraban $(\mathrm{n}=10)$ i Chios $(\mathrm{n}=10)$, kojima su uzeti uzorci krvi 2 i 4 mjeseca nakon parenja te 1,2 i 3 mjeseca nakon janjenja. Analizirane su serumske koncentracije glukoze, ukupnih proteina, albumina, globulina, aspartataminotransferaze, alanin-transaminaze, gama-glutamil transferaze, beta-hidroksi kiseline, neesteficiranih masnih kiselina, triglicerida, kolesterola, ukupnog HDL-a i LDL-a, direktnog i indirektnog bilirubina u svim uzorcima. Glukoza u ovaca pasmine Chios bila je znakovito povećana u odnosu na ovce pasmine Mehraban u svim ispitanim intervalima. Razine AST-a, ALT-a, GGT-a, triglicerida, kolesterola, HDL-a i LDL-a, betahidroksi kiseline i neesteficiranih masnih kiselina u Mehraban ovaca bile su znakovito veće nego u ovaca Chios u različitim intervalima prije i poslije janjenja. Rezultati istraživanja pokazuju da se metabolički i jetreni pokazatelji mijenjaju tijekom bređosti i laktacije što se odražava na energetske potrebe i metaboličke promjene u tim razdobljima. Nadalje, može se zaključiti da masnoća u repu ovaca Mehraban mijenja metaboličke i jetrene funkcije u te pasmine. Masnoća u repu može biti povezana s metabolizmom lipida i funkcijom jetre u peripartalnom razdoblju i može se pretpostaviti da polumasnorepe pasmine poput ovaca Chios mogu imati brži metabolizam zbog manjih zaliha masnoće.

Ključne riječi: masnoća u repu; jetreni pokazatelji; metabolički profil; ovce pasmina Chios i Mehraban

Vet. arhiv 89 (1), 43-53, 2019 
